\title{
INFLASI, TINGKAT BUNGA, DAN HARGA SAHAM
}

\author{
Herdiyana \\ Fakultas Ekonomi Universitas Pakuan \\ Email:sekdek@yahoo.com
}

\begin{abstract}
ABSTRAK
Tujuan dari penelitian ini adalah untuk mengetahui hubungan antara inflasi dengan suku bunga, serta pengaruh inflasi dan suku bunga secara parsial dan simultan terhadap IHSG. Penelitian yang dilakukan merupakan penelitian kuantitatif atau pengujian hipotesis. Objek dalam penelitian ini yaitu tingkat inflasi, tingkat suku bunga dan Indeks Harga saham Gabungan (IHSG). Periode penelitian yaitu dari tahun 2010 sampai 2015. Data yang digunakan merupakan data sekunder yang dikumpulkan secara elektronik. Metode analisis menggunakan regresi linier berganda dengan pengujian hipotesis uji statistik $\mathrm{t}$ dan uji statistik $\mathrm{F}$. Hasil penelitian menunjukkan bahwa: 1) antara inflasi dengan suku bunga terdapat hubungan yang signifikan; 2) antara inflasi dan suku bunga yang memiliki pengaruh signifikan terhadap IHSG adalah suku bunga. Namun secara simultan, kedua variabel tersebut berpengaruh signifikan terhadap IHSG.
\end{abstract}

\section{Kata Kunci: Inflasi, Tingkat Suku Bunga, dan Indeks Harga Saham Gabungan}

\section{PENDAHULUAN}

Widoatmodjo (2015, 11) menilai kondisi pasar modal, tidak bisa dilepaskan dari penilaian keseluruhan situasi ekonomi secara makro. Secara teori, kondisi pasar modal sangat dipengaruhi oleh penampilan ekonomi secara agregat. Hubungan antara pasar modal dan ekonomi makro menunjukan korelasi positif. Artinya, situasi ekonomi makro begitu besar pengaruhnya terhadap pasar modal. Pasar modal memegang peranan penting dalam perekonomian Indonesia dan nilai Indeks Harga Saham Gabungan (IHSG) dapat menjadi leading indikator ekonomi di Indonesia. Keberadaan pasar modal di Indonesia merupakan salah satu faktor penting dalam pembangunan perekonomian nasional, terbukti telah banyak industri dan perusahaan yang menggunakan institusi ini sebagai media untuk menyerap investasi dan media untuk memperkuat posisi keuangannya. Secara faktual pasar modal telah menjadi pusat saraf finansial (financial nerve centre) pada dunia ekonomi modern dewasa ini, bahkan perekonomian modern tidak akan mungkin dapat eksis tanpa adanya pasar modal yang tangguh dan berdaya saing global serta terorganisir dengan baik.

Samsul $(2006,200)$ menyatakan bahwa faktor makro merupakan faktor yang berada di luar perusahaan, tetapi mempunyai pengaruh terhadap kenaikan atau penurunan kinerja perusahaan baik secara langsung maupun tidak langsung. Faktor makro ekonomi yang secara langsung dapat mempengaruhi kinerja saham maupun kinerja perusahaan antara lain: 1 . Tingkat bunga umum domestik, 2. Tingkat inflasi, 3 . Peraturan perpajakan, 4. Kebijakan khusus pemerintah yang terkait dengan perusahaan tertentu, 5. Kurs valuta asing, 6. Tingkat bunga pinjaman luar negeri, 7. Kondisi perekonomian internasional, 8. Siklus ekonomi, 9. Paham ekonomi, dan 10. Peredaran uang.

Perubahan faktor makro ekonomi di atas tidak akan dengan seketika mempengaruhi kinerja perusahaan, tetapi secara perlahan dalam jangka panjang. Sebaliknya, harga saham akan terpengaruh dengan seketika oleh perubahan faktor makro ekonomi itu karena para investor lebih cepat bereaksi. Ketika perubahan faktor 
makro ekonomi itu terjadi, investor akan mengkalkulasi dampaknya baik yang positif maupun negatif terhadap kinerja perusahaan beberapa tahun ke depan, kemudian mengambil keputusan membeli atau menjual saham yang bersangkutan. Oleh karena itu, harga saham lebih cepat menyesuaikan diri daripada kinerja perusahaan terhadap perubahan variabel-variabel makro ekonomi.

Sahu $(2015,27)$ menyatakan "A wide range of macroeconomic indicators; namely, inflation, interest rates, money supply, industrial production index, gross domestic product, crude oil price, gold price, silver price, exchange rate, foreign exchange reserve, balance of payment, foreign direct investment, foreign institusional investment (FII), budget deficit, employment rate, foreign trade, international stock markets, small saving, RBI open market operation, and so on which can affect stock price."

Terdapat beberapa indikator yang mempengaruhi makro ekonomi diantaranya inflasi, suku bunga, uang beredar, indeks produksi industri, produk domestik bruto, harga minyak mentah, harga emas, harga perak, nilai tukar, cadangan devisa, dan lainlain.

Meningkatnya inflasi secara relatif adalah sinyal negatif bagi para investor. Dilihat dari sisi konsumen, inflasi yang tinggi akan mengakibatkan daya beli konsumen (masyarakat) menurun. Jika dilihat dari sisi perusahaan, inflasi dapat meningkatkan pendapatan dan biaya perusahaan. Jika peningkatan biaya faktor produksi lebih tinggi dari peningkatan harga yang dapat dinikmati oleh perusahaan, profitabilitas perusahaan akan menurun. Inflasi berdampak meningkatkan tingkat bunga. Meningkatnya tingkat bunga secara langsung akan meningkatkan beban bunga. Perusahaan yang mempunyai leverage yang tinggi akan mendapatkan dampak yang sangat berat terhadap kenaikan tingkat bunga. (Sunariyah, 2010, 22).
Penelitian ini bertujuan untuk mengetahui: 1) Hubungan antara inflasi dengan suku bunga, 2) Pengaruh inflasi dan suku bunga secara parsial dan simultan terhadap IHSG.

\section{KAJIAN LITERATUR Inflasi}

Putong $(2015,4)$ menyatakan bahwa "Inflasi adalah naiknya harga-harga komoditi secara umum yang disebabkan oleh tidak sinkronnya antara program sistem pengadaan komoditi (produksi, penentuan harga, pencetakan uang, dan lain sebagainya) dengan tingkat pendapatan yang dimiliki oleh masyarakat." Sedangkan Karya dan Syamsuddin (2016, 24) mengemukakan "Inflasi adalah kondisi terjadinya kenaikan haga-harga yang berlaku dalam suatu perekonomian secara terus-menerus."

Sependapat dengan Karya dan Syamsuddin, Fuguitt and Shanton $(1999,118)$ menyatakan bahwa "Inflation is an increase in the general price level of goods and services; it represents a reduction in a dollar's purchasing power."

Pendapat tersebut diperkuat oleh Bodie, Kane and Marcus $(2014,506)$ bahwa "Inflation is the rate at which the general level of prices is rising. High rates of inflation often are associated with "overheated" economies, that is, economies where the demand for goods and services is outstripping productive capacity, which leads to upward pressure on prices."

Menurut Kuncoro (2013) indikator yang sering digunakan untuk mengukur inflasi adalah Indeks Harga Konsumen (IHK). IHK merupakan satu indikator harga yang digunakan selama ini untuk melihat keberhasilan kebijakan moneter dalam mengendalikan inflasi, karena indikator ini dapat tersedia lebih cepat dibandingkan dengan indikator lain, seperti Indeks Harga Perdagangan Bebas (IHPB) dan PDB deflator Secara khusus, IHK merupakan indeks yang dipergunakan untuk mengukur rata-rata 
perubahan harga secara umum dari sejumlah jenis barang dalam kurun waktu tertentu atau disebut juga dengan inflasi. Perhitungan inflasi dijabarkan dengan rumus sebagai berikut:

$$
\text { Inflasi }=\frac{\mathrm{IHK}_{\mathrm{t}}-\mathrm{IHK}_{\mathrm{t}-1}}{\mathrm{IHK} \mathrm{t}_{\mathrm{t}-1}}
$$

Keterangan:

$\mathrm{IHK}_{\mathrm{t}}=$ Indeks Harga Konsumen Sekarang

$\mathrm{IHK}_{\mathrm{t}-1}=$ Indeks Harga Konsumen Sebelumnya

Menurut Idris $(2016,125)$ jenis inflasi menurut sifatnya dibagi menjadi tiga kategori utama, yaitu sebagai berikut: 1) Inflasi merayap/rendah (creeping inflation), yaitu inflasi yang besarnya kurang dari $10 \%$ pertahun; 2) Inflasi menengah (galloping inflation) besarnya antara $10-30 \%$ pertahun. Inflasi ini biasanya ditandai oleh naiknya harga-harga secara cepat dan relatif besar. Angka inflasi pada kondisi ini biasanya disebut 2 digit, misalnya 15\%, 20\%, 30\%, dan sebagainya; 3) Inflasi tinggi (high inflation), yaitu inflasi yang besarnya antara $30-100 \%$ per tahun. Dalam kondisi ini harga-harga secara umum naik; dan 4) Inflasi sangat tinggi (hyper inflation), yaitu inflasi yang ditandai oleh naiknya harga secara drastis hingga mencapai 4 digit (diatas 100\%). Pada kondisi ini masyarakat tidak ingin lagi menyimpan uang, karena nilainya merosot sangat tajam, sehingga lebih baik ditukarkan dengan barang.

Secara garis besar, dapat disimpulkan bahwa inflasi adalah keadaan ekonomi yang mengalami peningkatan harga barang dan jasa secara umum dan terus menerus serta tidak dapat dicegah dalam suatu perekonomian. Sifat inflasi terbagi menjadi tiga yaitu inflasi rendah, kurang dari $10 \%$ per tahun, inflasi menengah, berkisar 10\%-20\% per tahun, inflasi tinggi, berkisar 30\%-100\%, dan inflasi sangat tinggi di atas $100 \%$.

\section{Suku Bunga Sertifikat Bank Indonesia}

Menurut Tandelilin $(2010,343)$ tingkat bunga yang tinggi merupakan sinyal negatif terhadap harga saham. Disamping itu tingkat suku bunga yang meningkat bisa juga menyebabkan investor menarik investasinya pada saham dan memindahkannya pada investasi berupa tabungan ataupun deposito. Menguatnya kurs rupiah terhadap mata uang asing merupakan sinyal positif bagi perekonomian yang mengalami inflasi. Menguatnya kurs rupiah terhadap mata uang asing akan menurunkan biaya impor bahan baku untuk produksi, dan akan menurunkan tingkat suku bunga yang berlaku.

Menurut Liembono (2014, 108), “BI rate adalah suku bunga kebijakan yang mencerminkan sikap atau stance kebijakan moneter yang ditetapkan oleh Bank Indonesia dan diumumkan kepada publik."

Sahu $(2015,28)$ menjelaskan bahwa "Interest rate is one of the important macroeconomic variables that is directly related to economic growth. Generally, the interest rate is considered as the cost of capital, which means the price paid for the use of money for a period of time. The direction of interest rate movement is of primary importance to the stock market."

Tanuwidjaja (2006, 56) menjelaskan bahwa jika suku bunga naik, investor dapat mengalihkan uangnya dari saham ke deposito. Namun jika kenaikan suku bunga berbarengan dengan gejala melemahnya kurs rupiah secara signifikan, maka sebagian investor lebih baik menempatkan uangnya

JIMFE (Jurnal Ilmiah Manajemen Fakultas Ekonomi)

Volume 3 No. 1 Tahun 2017, Hal. 53-65 
dalam bentuk valuta asing. Jika suku bunga turun, investor lebih baik mengalihkan dananya dari deposito ke investasi saham.

Tandelilin (2010, 103) menguatkan pendapat Tanuwidjaja dengan menjelaskan bahwa "Perubahan suku bunga akan mempengaruhi harga saham secara terbalik, ceteris paribus. Jika suku bunga meningkat, maka harga saham akan turun, demikian juga sebaliknya jika suku bunga turun, harga saham akan naik."

BI rate mengimplikasi nilai dari suku bunga deposito maupun perbankan. $\mathrm{BI}$ rate dipengaruhi oleh tingkat inflasi. Semakin besar angka inflasi, $\mathrm{BI}$ rate akan menyesuaikan yang akhirnya suku bunga kredit perbankan juga akan dinaikkan. Semakin besar nilai inflasi, kemungkinan kredit yang gagal bayar semakin besar. Sehingga bank harus memperbesar suku bunga kredit. Beriringan dengan itu, dengan inflasi yang membesar, daya beli masyarakat menurun dan perusahaan makin sulit untuk meningkatkan penjualan dan menghasilkan laba. Sehingga sumber modal perusahaan akan bergantung pada pinjaman dari perbankan.

Liembono (2014, 109) menerangkan bahwa fungsi $\mathrm{BI}$ rate yang pertama adalah untuk mengendalikan inflasi. Jika suku bunga perbankan tinggi, masyarakat diharapkan lebih gemar menabung, mengerem belanja, dan mengerem kenaikan harga barang. Kedua, $\mathrm{BI}$ rate dapat mengendalikan pertumbuhan ekonomi. Jika $\mathrm{BI}$ rate rendah, suku bunga kredit perbankan juga akan rendah dan berimplikasi pada dunia usaha. Pengusaha akan semakin berani meminjam uang ke bank untuk ekspansi usaha, sehingga tenaga kerja terserap dan ekonomi bertumbuh lebih cepat.

Sunariyah (2004, 82) berpendapat bahwa fungsi dari suku bunga adalah sebagai berikut: 1) Sebagai daya tarik bagi para penabung yang mempunyai dana lebih untuk diinvestasikan; 2) Suku bunga dapat digunakan sebagai alat control bagi pemerintah terhadap dana langsung atau investasi pada sektor-sektor ekonomi; 3) Suku bunga dapat digunakan sebagai alat moneter dalam rangka mengendalikan penawaran dan permintaan uang yang beredar dalam suatu perekonomian. Misalnya, pemerintah mendukung pertumbuhan suatu sektor industri tertentu. Apabila perusahaan-perusahaan dari industri tersebut akan meminjam dana, maka pemerintah memberikan tingkat bunga yang lebih rendah dibandingkan sektor lain; dan 4) Pemerintah dapat memanipulasi tingkat bunga untuk meningkatkan produksi, sebagai akibatnya tingkat bunga dapat digunakan untuk mengkontrol tingkat inflasi.

Berdasarkan uraian tersebut, dapat disimpulkan bahwa suku bunga adalah akibat dari perubahan tingkat inflasi yang menyebabkan Bank Indonesia perlu mengubah tingkat $\mathrm{BI}$ rate. Namun, $\mathrm{BI}$ rate dan tingkat suku bunga nilainya tidak selalu sama. Perbankan memiliki kebijakan masingmasing untuk menetapkan suku bunganya namun harus menyesuaikan dengan $\mathrm{BI}$ rate. Pada intinya, acuan dari penelitian ini adalah $\mathrm{BI}$ rate yang digunakan untuk menstabilkan kondisi perekonomian dan menyeimbangkan antara penawaran tabungan dan permintaan investasi. Jika suku bunga meningkat, minat deposito akan meningkat. Namun jika suku bunga menurun permintaan investasi akan bertambah. Hal ini mengakibatkan harga saham menurun ketika suku bunga meningkat, dan meningkat ketika suku bunga menurun.

\section{Indeks Harga Saham}

Salah satu indikator pergerakan harga saham adalah indeks harga saham. Saat ini, BEI mempunyai beberapa macam indeks saham antara lain: 1) IHSG yang menggunakan semua perusahaan tercatat sebagai komponen perhitungan indeks; 2) Indeks sektoral yang menggunakan semua perusahaan tercatat yang termasuk dalam masing-masing sektor. Sekarang ini ada 10 
sektor yang ada di BEl yaitu sektor pertanian, pertambangan, industri dasar, aneka industri, barang konsumsi, properti, infrastruktur, keuangan, perdagangan dan jasa, dan manufaktur; 3) Indeks LQ45 yaitu indeks yang terdiri dari 45 saham perusahaan tercatat yang dipilih berdasarkan pertimbangan likuiditas dan kapitalisasi pasar, dengan kriteria-kriteria yang sudah ditentukan. Review dan penggantian saham dilakukan setiap 6 bulan; 4) Jakarta Islamic Index (JII) yaitu indeks yang menggunakan 30 saham yang dipilih dari saham-saham yang masuk dalam kriteria syariah (Daftar Efek Syariah yang diterbitkan oleh Bapepam-LK) dengan mempertimbangkan kapitalisasi pasar dan likuiditas; 5) Indeks Kompas 100 yaitu indeks yang terdiri dari 100 saham perusahaan tercatat yang dipilih berdasarkan pertimbangan likuiditas dan kapitalisasi pasar, dengan kriteria-kriteria yang sudah ditentukan. Review dan penggantian saham dilakukan setiap 6 bulan; 6) Indeks BISNIS-27. Kerja sama antara Bursa Efek Indonesia dengan harian Bisnis Indonesia meluncurkan indeks harga saham yang diberi nama Indeks BISNIS-27 yaitu indeks yang terdiri dari 27 saham perusahaan tercatat yang dipilih berdasarkan kriteria fundamental, teknikal atau likuiditas transaksi dan akuntabilitas dan tata kelola perusahaan; 7) Indeks PEFINDO25. Kerja sama antara Bursa Efek Indonesia dengan lembaga rating PEFINDO meluncurkan indeks harga saham yang diberi nama Indeks PEFINDO25. Indeks ini dimaksudkan untuk memberikan tambahan informasi bagi pemodal khususnya untuk saham-saham emiten kecil dan menengah (Small Medium Enterprises/SME). Indeks ini terdiri dari 25 saham perusahaan tercatat yang dipilih dengan mempertimbangkan kriteria-kriteria seperti: total aset, tingkat pengembalian modal (Return on Equity/ROE) dan opini akuntan publik. Selain kriteria tersebut di atas, diperhatikan juga faktor likuiditas dan jumlah saham yang dimiliki public; 8) Indeks SRI-KEHATI. Indeks ini dibentuk atas kerja sama antara Bursa Efek Indonesia dengan Yayasan Keanekaragaman Hayati Indonesia (KEHATI). SRI adalah kependekan dari Sustainable Responsible Investment. Indeks ini diharapkan memberi tambahan informasi kepada investor yang ingin berinvestasi pada emiten-emiten yang memiliki kinerja sangat baik dalam mendorong usaha berkelanjutan, serta memiliki kesadaran terhadap lingkungan dan menjalankan tata kelola perusahaan yang baik. Indeks ini terdiri dari 25 saham perusahaan tercatat yang dipilih dengan mempertimbangkan kriteri-kriteria seperti: total aset, Price Earning Ratio (PER) dan Free Float; 9) Indeks Papan Utama. Menggunakan saham-saham perusahaan tercatat yang masuk dalam Papan Utama; 10) Indeks Papan Pengembangan. Menggunakan sahamsaham perusahaan tercatat yang masuk dalam Papan Pengembangan; dan 11) Indeks Individual. Indeks harga saham masingmasing perusahaan tercatat di www.idx.co.id.

\section{Indeks Harga Saham Gabungan}

Menurut Widoatmodjo (2015, 13, Indeks Harga Saham Gabungan (IHSG) merupakan indeks yang merangkum perkembangan harga-harga saham di $\mathrm{BEI}$ (Bursa Efek Indonesia). IHSG pertama kali diperkenalkan pada tanggal 1 April 1983 sebagai indikator pergerakan harga saham yang tercatat di bursa. Hari dasar perhitungan indeks adalah tanggal 10 Agustus 1982 dengan nilai 100 dengan jumlah emiten yang tercatat sebanyak 13 emiten. Jumlah emiten yang tercatat di Bursa Efek Indonesia sampai dengan bulan desember 2009 mencapai 398 emiten. IHSG dalam Bahasa Inggris disebut juga Jakarta Composite Index, $\mathrm{JCl}$, atau JSX Composite.

Sunariyah (2006, 142) menyatakan IHSG adalah suatu nilai yang digunakan untuk mengukur kinerja gabungan seluruh saham yang tercatat di suatu bursa efek. IHSG di BEI meliputi pergerakan - pergerakan harga untuk saham biasa dan saham preferen. 
Samsul (2006, 185) mengemukakan bahwa IHSG (Composite Stock Price Index) merupakan indeks gabungan dari seluruh jenis saham yang tercatat di bursa efek. IHSG diterbitkan oleh bursa efek.

IHSG menggunakan semua perusahaan tercatat sebagai komponen perhitungan indeks agar IHSG dapat menggambarkan keadaan pasar yang wajar. Bursa Efek Indonesia berwenang mengeluarkan dan atau tidak memasukkan satu atau beberapa perusahaan tercatat dari perhitungan IHSG. Dasar pertimbanganya antara lain, jika jumlah saham perusahaan tercatat tersebut yang dimiliki oleh publik (free float) relatif kecil, sementara kapitalisasi pasarnya cukup besar. Sehingga perubahan harga saham perusahaan tercatat tersebut berpotensi mempengaruhi kewajaran pergerakan IHSG. Bursa Efek Indonesia tidak bertanggung jawab atas produk yang diterbitkan oleh pengguna yang mempergunakan IHSG sebagai acuan (benchmark). Bursa Efek Indonesia juga tidak bertanggungjawab dalam bentuk apapun atas keputusan investasi yang dilakukan oleh siapapun pihak yang menggunakan IHSG sebagai acuan (benchmark).

$$
I H S G=\frac{N P}{N D} \times 100 \%
$$

Keterangan:

NP : $\quad$ Rata-rata tertimbang nilai pasar (jumlah lembar tercatat di bursa dikalikan dengan harga pasar perlembarnya) dari saham umum dan saham preferen pada hari ke-t.

ND : Nilai dasar, yaitu kumulatif jumlah saham pada hari dasar dikali harga dasar pada hari dasar.

Berdasarkan uraian tersebut dapat disimpulkan bahwa IHSG adalah pergerakan harga indeks gabungan yang merangkum pergerakan harga-harga saham yang tercatat di Bursa Efek Indonesia (BEI).

\section{HIPOTESIS DAN METODE PENELITIAN}

Penelitian yang dilakukan merupakan penelitian kuantitatif atau pengujian hipotesis. Objek dalam penelitian ini yaitu tingkat inflasi, tingkat suku bunga dan IHSG. Periode penelitian yaitu dari tahun 2010 sampai 2015. Data yang digunakan merupakan data sekunder yang dikumpulkan secara elektronik. Metode analisis yang digunakan yaitu:

\section{Hipotesis}

Sesuai dengan tujuan penelitian, hipotesis dalam penelitian ini sebagai berikut.

\section{H1: Terdapat hubungan antara inflasi dengan suku bunga.}

Hipotesis statistik mengenai hubungan kedua variabel tersebut dapat dinyatakan sebagai berikut.

$$
\mathrm{H}_{0}: \rho \mathrm{x}_{1} \mathrm{x}_{2}=0
$$$$
H_{1}: \rho x_{1} x_{2}>0
$$

Secara grafis, hubungan tersebut dapat digambarkan sebagai berikut.

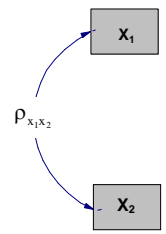

Gambar 1. Hubungan antara Variabel $\mathrm{X}_{1}$ dengan $\mathrm{X}_{2}$ 
Keterangan:

$\mathrm{X}_{1} \quad: \quad$ Variabel Inflasi (INF)

$\mathrm{X}_{2} \quad$ : Variabel Suku Bunga (SBI)

$\rho_{1} x_{2}$ : Hubungan antara Inflasi dengan

Suku Bunga

Hasil pengujian dikatakan signifikan jika p-value $<0,05$.

H2: Terdapat pengaruh inflasi dan suku bunga secara parsial dan simultan terhadap IHSG.

Hipotesis statistik mengenai pengaruh

$\mathrm{H}_{0}: \mathrm{Px}_{3} \mathrm{X}_{2}=0$

inflasi $\left(X_{1}\right)$ dan suku bunga $\left(X_{2}\right)$ terhadap IHSG

$\left(X_{3}\right)$ adalah sebagai berikut:

$\mathrm{H}_{1}: P \mathrm{X}_{3} \mathrm{X}_{2}>0$
$\mathrm{H}_{0}: \mathrm{Px}_{3} \mathrm{X}_{1}=0$
$\mathrm{H}_{1}: \mathrm{Px}_{3} \mathrm{X}_{1}>0$ dan
Secara grafis, pengaruh variabel $X_{1}$ dan $X_{2}$ terhadap $X_{3}$ dinyatakan sebagai berikut:

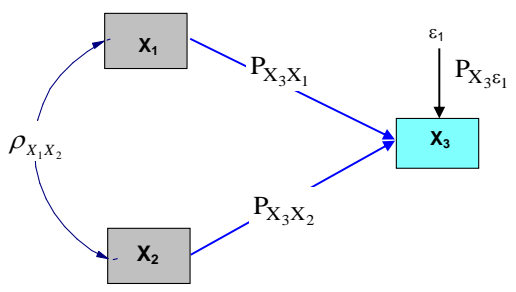

Gambar 2.

Pengaruh Variabel X1 dan X2 terhadap X3

Keterangan:

$\mathrm{X}_{1} \quad: \quad$ Variabel Inflasi (INF)

$\mathrm{X}_{2} \quad$ : Variabel Suku Bunga (SBI)

$X_{2}$ : Variabel Indeks Harga Saham

Gabungan (IHSG)

$\varepsilon \quad: \quad$ Variabel Lain yang Memiliki

Pengaruh terhadap IHSG

$\rho \mathrm{x}_{1} \mathrm{x}_{2}$ : Hubungan antara Inflasi dengan

Suku Bunga

$\mathrm{Px}_{3} \mathrm{X}_{1} \quad$ : $\quad$ Koefisien jalur dari $\mathrm{X}_{1}$ ke $\mathrm{X}_{3}$

$\mathrm{Px}_{3} \mathrm{X}_{2}$ : Koefisien jalur dari $\mathrm{X}_{2}$ ke $\mathrm{X}_{3}$

$\mathrm{Px}_{3} \varepsilon \quad$ : Koefisien jalur dari $\varepsilon$ ke $\mathrm{X}_{3}$ 
Persamaan struktural dari pengaruh $X_{1}$ dan $X_{2}$ terhadap $\mathrm{X}_{3}$ sebagai berikut:

$$
\mathrm{X}_{3}=P_{x_{3} x_{1}} \mathrm{x}_{1}+P_{x_{3} x_{2}} \mathrm{x}_{2}+P_{x_{3} \varepsilon} \varepsilon
$$

Besarnya pengaruh variabel inflasi dan suku bunga terhadap IHSG dapat dinyatakan dengan rinci sebagai berikut:

1) IHSG $\left(X_{3}\right)$ dipengaruhi oleh inflasi $\left(X_{1}\right)$

Pengaruh langsung dari $\mathrm{X}_{1}$ terhadap $\mathrm{X}_{3}$ $P_{x_{3} x_{1}} \cdot P_{x_{3} x_{1}}=\left(P_{x_{3} x_{1}}\right)^{2}$

Pengaruh tidak langsung $X_{1}$ terhadap $X_{3}$ melalui $\mathrm{X}_{2}$

$\mathrm{P}_{\mathrm{X}_{3} \mathrm{X}_{1}} \cdot \rho \mathrm{X}_{1} \mathrm{X}_{2} \cdot \mathrm{P}_{\mathrm{X}_{3} \mathrm{X}_{2}}$

Total pengaruh $\mathrm{X}_{1}$ terhadap $\mathrm{X}_{3}$

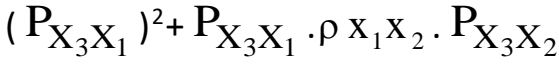

2) IHSG $\left(X_{3}\right)$ dipengaruhi oleh suku bunga $\left(\mathrm{X}_{2}\right)$

Pengaruh langsung dari $\mathrm{X}_{2}$ terhadap $\mathrm{X}_{3}$

$P_{x_{3} x_{2}} \cdot P_{x_{3} x_{2}}=\left(P_{x_{3} x_{2}}\right)^{2}$

Pengaruh tidak langsung $X_{2}$ terhadap $X_{3}$ melalui $\mathrm{X}_{1}$

$$
\mathrm{P}_{\mathrm{X}_{3} \mathrm{X}_{2}} \cdot \rho \mathrm{X}_{1} \mathrm{X}_{2} \cdot \mathrm{P}_{\mathrm{X}_{3} \mathrm{X}_{1}}
$$

Total pengaruh $\mathrm{X}_{2}$ terhadap $\mathrm{X}_{3}$

$\left(P_{X_{3} X_{2}}\right)^{2}+P_{X_{3} X_{2}} \cdot \rho \mathrm{x}_{1} \mathrm{x}_{2} \cdot P_{X_{3} X_{1}}$

Total pengaruh inflasi $\left(X_{1}\right)$ dan suku bunga $\left(X_{2}\right)$ terhadap IHSG $\left(X_{3}\right)$ yaitu:

$$
\begin{aligned}
& R^{2} \times 3 \times 1 \times 2=P_{1}+P_{2} \\
& \text { Di mana: } \\
& P_{1}=\left(P_{X_{3} X_{1}}\right)^{2} \\
& +P_{X_{3} X_{1}} \cdot \rho X_{1} X_{2} \cdot P_{X_{3} X_{2}} \\
& P_{2}=\left(P_{X_{3} X_{2}}\right)^{2}{ }_{+} P_{X_{3} X_{2}} \bullet \rho X_{1} X_{2} \bullet \\
& P_{X_{3} X_{1}}
\end{aligned}
$$

Total pengaruh faktor lain selain inflasi dan suku bunga $(\varepsilon)$ adalah $1-R^{2} \times 3 \times 1 \times 2$ sedangkan koefisien jalurnya yaitu:

$$
P_{X_{3}} \varepsilon=\sqrt{1-R^{2} X_{3} X_{1} X_{2}}
$$

\section{HASIL PENELITIAN DAN PEMBAHASAN}

\section{Hasil Penelitian}

Berdasarkan hasil pengumpulan data dapat diperoleh hasil sebagai berikut:

Tabel 1. Rata-rata Inflasi, Suku Bunga dan IHSG Periode 2010-2015

\section{RATA-RATA}

\begin{tabular}{|c|c|c|c|}
\multirow{2}{*}{ Tahun } & \multicolumn{3}{|c|}{ RATA-RATA } \\
\cline { 2 - 4 } & Inflasi & Suku Bunga & IHSG \\
\hline $\mathbf{2 0 1 0}$ & 0,0513 & 0,0650 & 3095,1275 \\
\hline $\mathbf{2 0 1 1}$ & 0,0538 & 0,0658 & 3746,0687 \\
\hline $\mathbf{2 0 1 2}$ & 0,0428 & 0,0577 & 4118,8279 \\
\hline $\mathbf{2 0 1 3}$ & 0,0697 & 0,0648 & 4606,2464 \\
\hline $\mathbf{2 0 1 4}$ & 0,0642 & 0,0752 & 4937,4593 \\
\hline $\mathbf{2 0 1 5}$ & 0,0638 & 0,0752 & 4875,2104 \\
\hline
\end{tabular}

Sumber: data diolah 


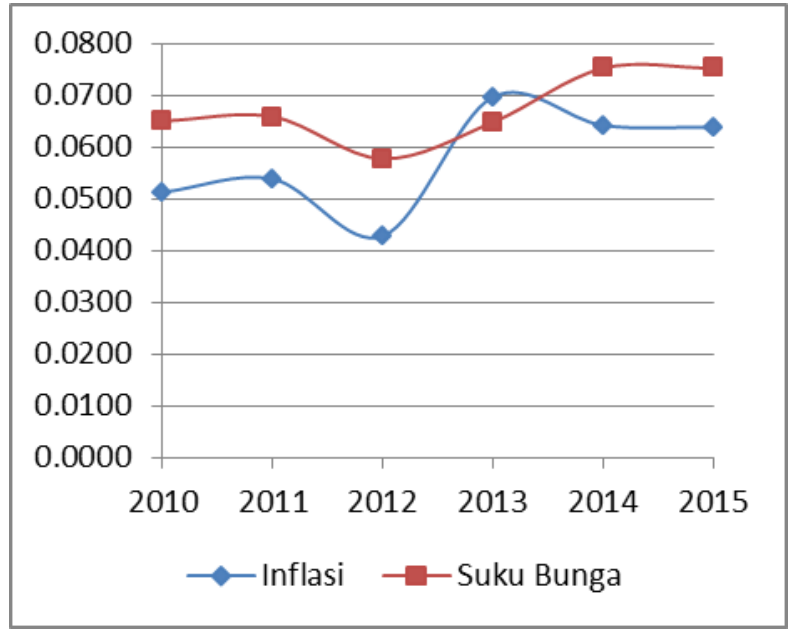

Gambar 3.

Pegerakan Rata-Rata Tingkat Inflasi dan Suku Bunga Periode 2010 - 2015

Berdasarkan Tabel 1 dan Gambar 2 dapat diketahui pergerakan rata-rata tingkat inflasi berfluktuasi dari tahun ke tahun. Penurunan paling besar terjadi pada tahun 2012 dibandingkan tahun lainnya, tingkat inflasi turun sebesar 20\%. Akan tetapi kembali meningkat pada tahun 2013 sebesar
63\%. Begitu pula dengan suku bunga, dari tahun ke tahun berfluktuasi, penurunan terbesar terjadi pada tahun 2012 dibandingkan tahun lainnya yaitu sebesar $12 \%$ dan peningkatan tertinggi terjadi pada tahun 2014, meningkat sebesar $16 \%$ dibandingkan tahun 2013.

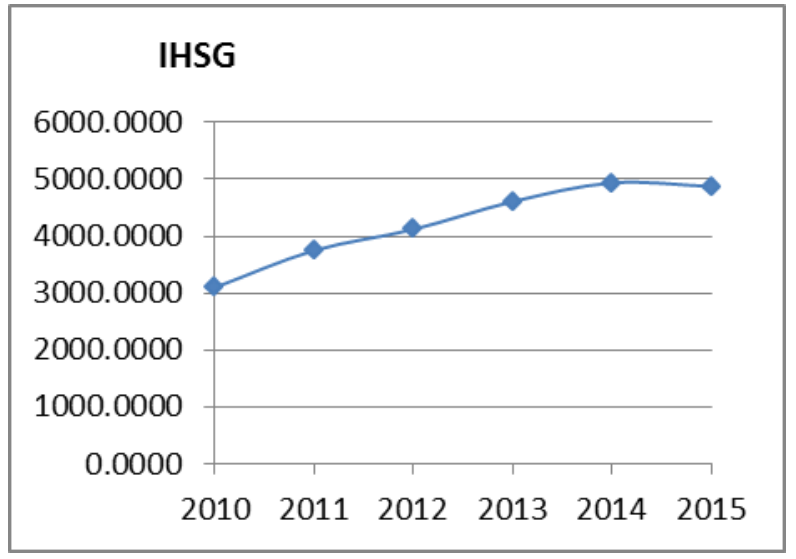

Gambar 4.

Pergerakan Rata-rata IHSG Periode 2010-2015

Berbeda dengan pergerakan tingkat inflasi dan suku bunga, IHSG dari tahun 2010 - 2014 selalu mengalami peningkatan dan hanya tahun 2015 yang mengalami penurunan dibandingkan tahun 2014, yaitu turun sebesar $1 \%$. 


\section{Hasil Pengolahan Data dan Pembahasan}

\section{Correlations}

\begin{tabular}{|ll|r|r|r|}
\hline & & IHSG & INF & SBI \\
\hline \multirow{4}{*}{ IHSG } & Pearson & 1 &, 346 &, 415 \\
& Correlation & 1 & $* *$ & $* *$ \\
& Sig. (1-tailed) & &, 001 &, 000 \\
& $\mathrm{~N}$ & 72 & 72 & 72 \\
& Pearson &, 346 & &, 552 \\
INF & Correlation & ${ }^{* *}$ & 1 & $* *$ \\
& Sig. (1-tailed) &, 001 & &, 000 \\
& N & 72 & 72 & 72 \\
& Pearson &, 415 &, 552 & \\
& Correlation & $*$ & $*$ & 1 \\
SBI & Sig. (1-tailed) &, 000 &, 000 & \\
& N & 72 & 72 & 72 \\
\hline
\end{tabular}

**. Correlation is significant at the 0.01 level (1-tailed).

Berdasarkan tabel di atas dapat diketahui bahwa hubungan antara IHSG baik dengan inflasi maupun suku bunga memiliki hubungan yang signifikan. Hal itu ditunjukkan oleh nilai Sig. (1-tailed) untuk masing-masing variabel independen $<0,05$. Dengan demikian, hipotesis 1 yang menyatakan terdapat hubungan antara inflasi dengan suku bunga terbukti.

Variables Entered/Removed ${ }^{\mathrm{a}}$

\begin{tabular}{|l|l|l|l|}
\hline Model & $\begin{array}{c}\text { Variables } \\
\text { Entered }\end{array}$ & $\begin{array}{c}\text { Variables } \\
\text { Removed }\end{array}$ & $\begin{array}{c}\text { Metho } \\
\mathrm{d}\end{array}$ \\
\hline 1 & $\mathrm{SBI}$, INF & & Enter \\
\hline
\end{tabular}

a. Dependent Variable: IHSG

b. All requested variables entered.

Model Summary

\begin{tabular}{|l|c|r|r|r|}
\hline $\begin{array}{l}\text { Mod } \\
\text { el }\end{array}$ & $\mathrm{R}$ & $\begin{array}{r}\mathrm{R} \\
\text { Square }\end{array}$ & $\begin{array}{c}\text { Adjusted R } \\
\text { Square }\end{array}$ & $\begin{array}{r}\text { Std. Error of } \\
\text { the Estimate }\end{array}$ \\
\hline 1 & $\begin{array}{r}438 \\
\mathrm{a}\end{array}$ &, 192 &, 168 & 662,78969 \\
\hline
\end{tabular}

a. Predictors: (Constant), SBI, INF

\begin{tabular}{|c|c|c|c|c|c|c|}
\hline \multicolumn{7}{|c|}{ ANOVA $^{a}$} \\
\hline Model & & $\begin{array}{l}\text { Sum of } \\
\text { Squares }\end{array}$ & df & Mean Square & $\mathrm{F}$ & Sig. \\
\hline \multirow[t]{3}{*}{\begin{tabular}{|l|}
1 \\
\end{tabular}} & Regression & 7186226,412 & 2 & 3593113,206 & 8,179 & $.001^{\mathrm{b}}$ \\
\hline & Residual & 30311021,53 & 69 & 439290,167 & & \\
\hline & Total & 37497247,94 & 71 & & & \\
\hline
\end{tabular}

b. Predictors: (Constant), SBI, INF 


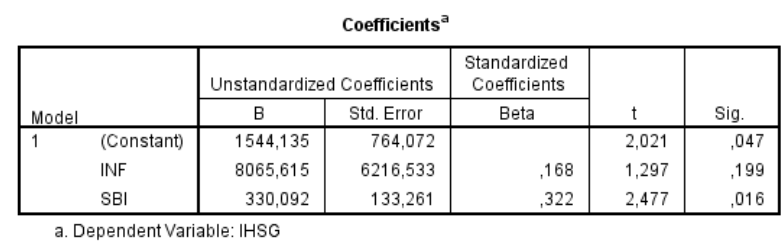

a. Dependent Variable: IHSO

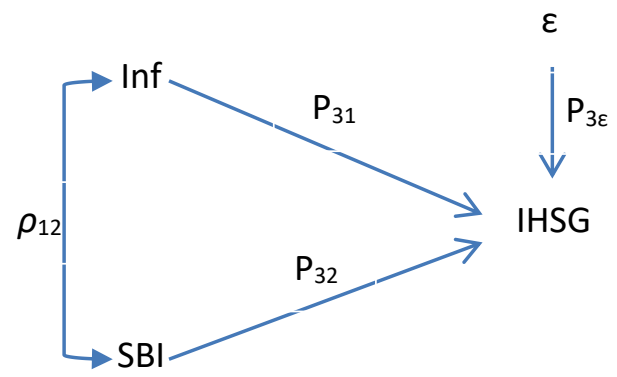

Proposisi hipotesis yang diajukan oleh peneliti bisa diterjemahkan ke dalam diagram jalur seperti di bawah ini :

Pada diagram jalur ini terdapat dua buah variabel eksogen yaitu Inf (inflasi) dan SBI (suku bunga), serta sebuah variabel endogen, yaitu IHSG. Berdasarkan hasil pengolahan data, maka bentuk persamaan struk tural untuk diagram jalur di atas yaitu:

IHSG $=0,168 \mathrm{INF}+0,322 \mathrm{SBI}+\varepsilon$

Model ini siginifikan karena $p$-value untuk nilia $\mathrm{F}$ sebesar $0,001<0,05$. Hal ini juga membuktikan bahwa secara simultan variabel inflasi dan suku bunga berpengaruh signifikan terhadap IHSG. Dengan demikian, hipotesis 2 terbukti.

Koefisien jalur untuk $P_{31}$ yang menunjukkan pengaruh inflasi terhadap IHSG tidak signifikan karena $p$-value $=0,199>0,05$. Sedangkan koefisien jalur untuk $p_{32}$ yang menunjukkan pengaruh suku bunga terhadap IHSG signifikan karena $p$-value $=0,016<0,05$. Sedangkan koefisien jalur untuk $\varepsilon\left(p_{3 \varepsilon}\right)$ yaitu:

$$
p_{3 \varepsilon}=\sqrt{1-R^{2}}=\sqrt{1-0,192}=0,899
$$

Hubungan struktural antara inflasi (Inf), suku bunga (SBI) dan IHSG sebagai berikut:

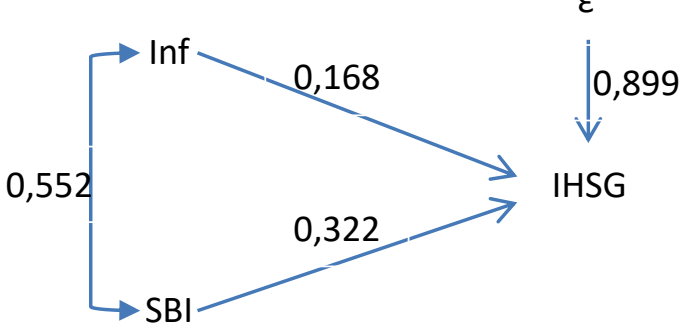

Berdasarkan data tersebut, maka dapat dihitung pengaruh langsung, tidak langsung dan pengaruh total dari $X_{1}$ (inflasi) terhadap $\mathrm{X}_{3}$ (IHSG) dan $\mathrm{X}_{2}$ (SBI) terhadap $\mathrm{X}_{3}$ (IHSG) sebagai berikut.

IHSG $\left(X_{3}\right)$ dipengaruhi oleh inflasi $\left(X_{1}\right)$

Pengaruh langsung dari $X_{1}$ terhadap $X_{3}$

$$
P_{x_{3} x_{1}} \cdot P_{x_{3} x_{1}}=\left(P_{x_{3} x_{1}}\right)^{2}=(0,168)^{2}=0,028
$$


Pengaruh tidak langsung $X_{1}$ terhadap $X_{3}$ melalui $\mathrm{X}_{2}$

$$
\begin{aligned}
& P_{X_{3} X_{1}} \cdot \rho X_{1} X_{2} \cdot P_{X_{3} X_{2}} \\
& =(0,168) \cdot(0,552) \cdot(0,322)=0,030
\end{aligned}
$$

Total pengaruh $\mathrm{X}_{1}$ terhadap $\mathrm{X}_{3}$

$$
\begin{aligned}
& \left(P_{X_{3} X_{1}}\right)^{2}+P_{X_{3} X_{1}} \cdot \rho X_{1} X_{2} \cdot P_{X_{3} X_{2}} \\
& =(0,168)^{2}+\{(0,168) \cdot(0,552) \cdot(0,322)\} \\
& =0,028+0,030 \\
& =0,058
\end{aligned}
$$

\section{IHSG $\left(X_{3}\right)$ dipengaruhi oleh suku bunga $\left(X_{2}\right)$}

Pengaruh langsung dari $X_{2}$ terhadap $X_{3}$

$$
P_{x_{3} x_{2}} \cdot P_{x_{3} x_{2}}=\left(P_{x_{3} x_{2}}\right)^{2}=(0,322)^{2}=0,104
$$

Pengaruh tidak langsung $\mathrm{X}_{2}$ terhadap $\mathrm{X}_{3}$ melalui $X_{1}$

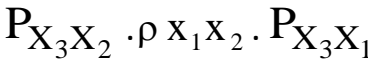

$$
\begin{aligned}
& =(0,322) \cdot(0,552) \cdot(0,168)=0,030
\end{aligned}
$$

Total pengaruh $\mathrm{X}_{2}$ terhadap $\mathrm{X}_{3}$

$$
\begin{aligned}
& \left(P_{X_{3} X_{2}}\right)^{2}+P_{X_{3} X_{2}} \cdot \rho \mathrm{x}_{1} \mathrm{x}_{2} \cdot P_{X_{3} X_{1}} \\
& =(0,322)^{2}+\{(0,322) \cdot(0,552) \cdot(0,168)\} \\
& =0,104+0,030 \\
& =0,134
\end{aligned}
$$

Atau dapat dihitung dengan cara:

Total pengaruh dari inflasi $\left(X_{1}\right)$ terhadap IHSG $\left(X_{3}\right)$ :

$$
\begin{aligned}
\operatorname{TP}_{x 3 \times 1} & =\beta_{x 1} \cdot \rho_{x 3 \times 1} \\
\operatorname{TP}_{x 3 \times 1} & =(0,168) \cdot(0,346)=0,058 .
\end{aligned}
$$

Sedangkan total pengaruh dari suku bunga $\left(\mathrm{X}_{2}\right)$ terhadap IHSG $\left(\mathrm{X}_{3}\right)$ :

$\mathrm{TP}_{\mathrm{x} 3 \times 2}=\beta_{\mathrm{x} 1} \cdot \rho_{\mathrm{x} 3 \mathrm{x} 2}$

$\operatorname{TP}_{\times 3 \times 2}=(0,322) \cdot(0,415)=0,134$.
Dengan demikian, total pengaruh inflasi $\left(X_{1}\right)$ dan suku bunga $\left(X_{2}\right)$ terhadap IHSG $\left(X_{3}\right)$ yaitu:

$$
\begin{aligned}
& R^{2} \times 3 \times 1 \times 2=P_{1}+P_{2} \\
& R^{2} \times 3 \times 1 \times 2=0,058+0,134=0,192
\end{aligned}
$$

Total pengaruh faktor lain selain inflasi dan suku bunga $(\varepsilon)$ adalah $1-R^{2} \times 3 \times 1 \times 2=1-$ $0,192=0,808$. Sedangkan koefisien jalurnya yaitu:

$$
\frac{P_{X_{3}} \varepsilon}{\sqrt{1-R^{2}{ }_{X_{3} X_{1} X_{2}}}}=\sqrt{0,808}=0,899
$$

\section{KESIMPULAN}

Berdasarkan hasil penelitian maka dapat disimpulkan bahwa: 1) antara inflasi dengan suku bunga terdapat hubungan yang signifikan; 2) antara inflasi dan suku bunga yang memiliki pengaruh signifikan terhadap IHSG adalah suku bunga. Namun secara simultan, kedua variabel tersebut berpengaruh signifikan terhadap IHSG.

Walaupun kedua variabel tersebut berpengaruh terhadap IHSG, namun pengaruhnya relatif kecil. Pengaruh dari inflasi terhadap IHSG hanya sebesar 0,058 atau $5,8 \%$ sedangkan pengaruh dari suku bunga sebesar 0,134 atau 13,4\%. Dengan demikian, pengaruh dari kedua variabel tersebut terhadap IHSG sebesar 0,192 atau $19,2 \%$ dan sisanya sebesar 0,808 atau $80,8 \%$ merupakan pengaruh dari faktor lain.

Hal tersebut tidak mengherankan, karena masih banyak faktor atau variabel makro lain yang mempengaruhi IHSG selain variabel inflasi dan suku bunga. Faktor atau variabel makro lainnya itu antara lain: peraturan perpajakan, kebijakan khusus pemerintah yang terkait dengan perusahaan tertentu, kurs valuta asing, tingkat bunga pinjaman luar negeri, kondisi perekonomian internasional, siklus ekonomi, paham ekonomi, dan peredaran uang. 


\section{SARAN}

Berdasarkan hasil penelitian dan simpulan tersebut, maka disarankan untuk penelitian lainnya yang berkaitan dengan variabel IHSG agar menambah atau memasukkan variabel makro lainnya selain variabel inflasi dan suku bunga.

Selain itu, karena dalam penelitian ini data yang digunakan yaitu data bulanan dari inflasi, suku bunga dan IHSG, maka untuk penelitian lainnya dapat menggunakan data dengan periode yang berbeda, seperti per tri wulan atau bahkan per hari.

\section{DAFTAR PUSTAKA}

Amiruddin Idris. 2016. Ekonomi Publik. Yogyakarta: Deepublish.

Bodie Z., Kane A., and Marcus A.Z. 2014. Investment, $10^{\text {th }}$ edition. New York McGraw-Hill.

Detri Karya dan Syamri Syamsuddin. 2016. Makro Ekonomi: Pengantar untuk Manajemen. Jakarta: PT RajaGrafindo Persada.

Eduardus Tandelilin. 2010. Portofolio dan Investasi Teori dan Aplikasi. Edisi Pertama. Kanisius: Yogyakarta.

Fuguitt, Diana and Shanton J. Wilcox. 1999. Cost-Benefit Analysis for Public Sector Decision Makers, Westport CN, Quorum Books.
Iskandar Putong. 2015. Pengantar Ekonomi Makro. Jakarta: Mitra Wacana Media.

Mohammad Samsul. 2006. Pasar Modal dan Manajemen Portofolio. Surabaya: Erlangga.

RH. Liembono. 2014. Analisis Fundamental. Jakarta: BEI5000.

Sahu, Tarak Nath. 2015. Macroeconomic Variables and Security Prices in India during the Liberalized Period. New York: Palgrave Macmillan.

Sawidji Widoatmodjo. 2015. Pengetahuan Pasar Modal: untuk Konteks Indonesia. Jakarta: PT Elex Media Komputindo.

Sunariyah. 2006. Pengantar Pengetahuan Pasar Modal. Edisi Kelima. Yogyakarta: UPP STIM YKPN.

Sunariyah. 2010. Pengantar Pengetahuan Pasar Modal. Edisi ke-6. Yogyakarta: UPP-AMP YKPN.

Wiliam Tanuwidjaja. 2006. Siasat Investasi Cerdik: Bagi Investor Pemula. Yogyakarta: PT buku Kita.

\section{Web}

www.bi.go.id.

www.bps.go.id.

www.finance.yahoo.com.

www.idx.co.id. 